\title{
Antigenic assessment of a recombinant human CD90 protein expressed in prokaryotic expression system
}

Narges Yousefi-Rad ${ }^{1}$, Mohammad Ali Shokrgozar ${ }^{2}$, Mahdi Behdani ${ }^{3}$, Shima Moradi- Kalbolandi Mahdieh Motamedi-Rad ${ }^{4}$, Mahdi Habibi-Anbouhi ${ }^{2} *$

${ }^{1}$ Pharmaceutical Sciences Branch, Islamic Azad University, Tehran, Iran

${ }^{2}$ National Cell Bank of Iran, Pasteur Institute of Iran, Tehran, Iran

${ }^{3}$ Biotechnology Research Center, Pasteur Institute of Iran, Tehran, Iran

${ }^{4}$ Department of Hepatitis and AIDs, Pasteur Institute of Iran, Tehran, Iran

\section{* Corresponding author:}

Mahdi Habibi-Anbouhi, National Cell Bank of Iran, Pasteur Institute of Iran, Tehran, Iran.

Tel. \& Fax; +9821-66492595, Email addresses: habibi_m@pasteur.ac.ir 


\begin{abstract}
:
Cluster of Differentiation 90 (CD90, Thy-1) has been proposed as one of the most important biomarkers in several cancer cells including cancer stem cells (CSCs). CD90 is considered as a potential normal stem cell and CSCs biomarker and also has been identified in lung cancer stem cells, hepatocellular carcinoma cells and high-grade gliomas.
\end{abstract}

Using eukaryotic host systems involves complex procedures and frequently results in low protein yields. The expression of recombinant proteins in Escherichia coli is comparatively easier than eukaryotic host cells. The potential of large scale production of recombinant protein has made this system an economic production platform.

In this study we expressed the extra-membrane domain of human CD90 (exCD90) antigen $\left(\mathrm{Gln}_{15}-\mathrm{Cys}{ }_{130}\right)$ in E. coli expression host cells. The epitope integrity of purified recombinant antigen was confirmed by antibody-antigen interaction using 5E10 antiCD90 monoclonal antibody and binding study through ELISA and florescent staining of $\mathrm{CD}^{+} 0^{+}$cells in a flow cytometry experiment.

\title{
Key words:
}

Human CD90 (Thy-1), Prokaryotic expression system, Escherichia coli (E.coli), Recombinant protein 


\begin{abstract}
Abbreviations:
Cluster of Differentiation 90 (CD90), Cancer Stem Cells (CSCs), Extra-Membrane Domain of Human CD90 (exCD90), Escherichia coli (E.coli), Enzyme-Linked Immunosorbent Assay (ELISA), Monoclonal Antibody (mAb), Polyclonal Antibody (pAb), Isopropyl- $\beta$-D Thiogalactopyranoside (IPTG), Optical Density (OD), 3, 3'Diaminobenzidine (DAB).
\end{abstract}

\title{
1- Introduction
}

The distinction between the tumor- and non-tumor-initiating cells is based on the expression of some "biomarkers". A biomarker could be a cell surface molecule, a gene expression profile, a signature or differential expression or activation level of a transcription regulator, enzyme or miRNAs [1-5]. Biomarkers can be used in diagnosis, characterization, prognosis, or targeting of malignancies.

Cluster of Differentiation 90 (CD90, Thy-1) has been proposed as one of the most important biomarkers in several cancer cells including cancer stem cells (CSCs) [6]. CD90 is a cell adhesion molecule and the smallest member of the immunoglobulin superfamily with a molecular weight of 25-35 kDa [7-9]. CD90 molecule is expressed on the cell surface of mature neurons, fibroblast, endothelial cells (conditionally), mesenchymal cells, as well as on T-cells [10-15]. CD90 plays a role in growth and differentiation of stem cells and is now considered as a potential normal and cancer stem 
cell biomarker and has been identified in lung cancer stem cells [16], hepatocellular carcinoma cells [17] and high-grade gliomas [6].

Expression of recombinant ligand and receptors is a powerful tool in the study of structure-function relationships of membrane proteins, e.g., of components mediating intracellular traffic, and production of poly and monoclonal antibodies. Using eukaryotic host systems such as yeast, insect or mammalian cells involves complex procedures and frequently results in low protein yields $[18,19]$. The expression of recombinant proteins in Escherichia coli prokaryotic host cells is comparatively easier than eukaryotic systems. The potential of large scale production of recombinant protein due to high-level bacterial expression, has made this system an economic production platform for recombinant proteins [20-23].

The human CD90 antigen has been produced in different formats and expression systems including Fc fusion full length protein in HEK 293 cells (Abcam, cat No. ab157072), recombinant fragment in yeast (Antibodies-online, cat No. ABIN1465834), recombinant protein with GST-tag by in vitro wheat germ expression system (Abnova, cat No. H00007070-Q01) and N-terminal His6-Albumin binding fusion protein in E.coli (Atlas Antibodies, cat No. APrEST77497). In this study, we expressed the extra-membrane domain of human CD90 (exCD90) antigen $\left(\mathrm{Gln}_{15}-\mathrm{Cys}_{130}\right)$ in E. coli expression host cells in order to achieve a functional human CD90 recombinant protein with appropriate antigenic characteristic. The epitope integrity of purified recombinant antigen was confirmed by antibody-antigen interaction using an anti-CD90 monoclonal antibody and 
binding study through enzyme-linked immunosorbent assay (ELISA) and florescent staining of $\mathrm{CD} 90^{+}$cells in a flow cytometry experiment.

\section{2- Materials and Methods:}

\section{2-1- Cloning, expression and purification:}

The coding sequence of extra-membrane domain of human CD90 gene (NCBI Reference Sequence, NM_006288.3) from $\mathrm{Gln}_{15}$ to $\mathrm{Cys}_{130}, 116$ amino acids and $348 \mathrm{bp}$, was codon optimized and synthesized (Genecust, Luxemburg). NcoI and BamHI restriction sites were designed at the $5^{\prime}$ and 3 ' ends of sequence respectively. A $6 \times$ His tag was included at the $C$-terminus of sequence before TAA stop codon (Figure 1). The synthesized gene was digested with $\mathrm{NcoI}$ and BamHI restriction enzymes (Thermo Scientific, USA), gelextracted by GenElute Gel Extraction Kit (Sigma, Germany), and ligated into NcoI/BamHI double-digested pET-15b prokaryotic expression vector (Merck-Millipore, USA) using T4 DNA ligase (Thermo Scientific, USA). The cloning was confirmed by enzymatic digestion with EcoRI restriction enzyme and colony PCR using FpET15bCD90, GCTTCCTTTCGGGCTTTGTT, and RpET15bCD90, GTCGATCAGTCGTTGCGT, primers.

The recombinant vector was transformed into E. coli Rosetta (DE3) competent cells (Merck-Millipore, USA) according to calcium chloride $(\mathrm{CaCl} 2)$ protocol as described by Sambrook et al. (1989). A single colony was inoculated into $200 \mathrm{~mL}$ terrific broth 
medium supplemented with $100 \mu \mathrm{g} / \mathrm{mL}$ ampicillin and cultured in a $37^{\circ} \mathrm{C}$ incubator at $200 \mathrm{rpm}$. The expression of exCD90 protein was induced by adding $0.5 \mathrm{mM}$ of isopropyl$\beta$-D thiogalactopyranoside (IPTG) (Sigma, Germany) at optical density (OD600) of 0.6 at $28^{\circ} \mathrm{C}$ for $16 \mathrm{~h}, 200 \mathrm{rpm}$.

The culture was harvested by centrifugation at $4500 \mathrm{~g}$ for $15 \mathrm{~min}$ at $4^{\circ} \mathrm{C}$ and the cell pellet were resuspended in $7 \mathrm{~mL}$ lysis buffer [300 mM NaCl, $10 \mathrm{mM}$ imidazole (Applichem, Germany), $50 \mathrm{mM} \mathrm{NaH} \mathrm{PO}_{4} \mathrm{pH}$ 7.4]. Cell lysate was prepared by sonication and centrifugation at $6000 \mathrm{~g}$ for $30 \mathrm{~min}$ at $4^{\circ} \mathrm{C}$.

The clarified cell lysate was diluted by PBS, 50/50, and applied to $0.5 \mathrm{~mL}$ HisPur $^{\mathrm{TM}} \mathrm{Ni}-$ NTA Resin (Thermo Scientific, USA) which was packed into a $2 \mathrm{~mL}-$ Pierce ${ }^{\mathrm{TM}}$ Centrifuge Column (Thermo Scientific, USA). After a $20 \mathrm{~min}$-short time incubation in RT, to prevent non-specific binging, the column was washed with $10 \mathrm{~mL}$ of washing buffer, 25 $\mathrm{mM}$ imidazole in PBS. The recombinant exCD90 was eluted by $0.5 \mathrm{~mL}$ elution buffer, $250 \mathrm{mM}$ imidazole in PBS. In order to remove the imidazole, the eluent was buffer exchanged by PBS using Vivaspin $500 \mu \mathrm{l}$ (Sartorius, Germany) according to the manufacturer's instructions.

\section{2-2- SDS-PAGE and western blot analysis:}

The recombinant exCD90 protein was analyzed for protein expression by SDS-PAGE.

The prepared protein samples including cell lysate, flow-through, final wash and eluted 
exCD90 were subjected to electrophoresis on a $15 \%$ polyacrylamide gel and was stained by silver staining [24]. For western blotting, the protein on the SDS-PAGE gel was transferred to a nitrocellulose membrane. The membrane was blocked with $1 \%$ casein blocking buffer and incubated with $2 \mu \mathrm{g} / \mathrm{mL}$ in PBS of 5E10 anti-CD90 monoclonal antibody [25] (eBioscience, USA) and with 1:1500 dilution of anti-mouse HRP conjugate (Sigma, Germany). The specific band was revealed by 3, 3'-Diaminobenzidine (DAB) solution (Sigma, Germany).

\section{2-3- In vitro binding study:}

The antigen-antibody interaction was studied through an ELISA experiment using the 5E10 anti-CD90 monoclonal antibody. Briefly, an ELISA plate was coated with $100 \mu \mathrm{l}$ of the recombinant exCD90 protein $(2 \mu \mathrm{g} / \mathrm{mL})$. After washing with PBST (PBS with $0.05 \%$ Tween 20), the plate was blocked with $100 \mu \mathrm{l} /$ well of $4 \%$ skim milk for $1 \mathrm{~h}$ at $37^{\circ} \mathrm{C}$. Following three washes with PBST, 100 $\mu 1$ 5E10 anti-CD90 monoclonal antibody (5 $\mu \mathrm{g} / \mathrm{mL}$ in PBS) was added to each well and incubated for $1.5 \mathrm{~h}$ at $37^{\circ} \mathrm{C}$. Then, after washing, $100 \mu \mathrm{l}$ of anti-mouse HRP conjugate, 1:4000 in PBS, was added to each well followed by $1 \mathrm{~h}$ incubation at $37^{\circ} \mathrm{C}$ and were washed for three times. Finally, $75 \mu \mathrm{l}$ of TMB substrate (Sigma, Germany) was added into each well, and incubated in $37^{\circ} \mathrm{C}$ for 5 min in the dark. The reaction was stopped by adding $75 \mu$ of stopping buffer $\left(\mathrm{H}_{2} \mathrm{SO}_{4} 0.5\right.$ $\mathrm{N})$ to each well. The absorbance at $450 \mathrm{~nm}$ was determined by ELISA reader. PBS was used as negative control and experiment was performed in triplicate for all samples. 


\section{2-4- Production of anti-recombinant exCD90 polyclonal antibody:}

A New Zealand White female rabbits, 8 weeks old, was immunized 5 times in two-week intervals by subcutaneously injection of $200 \mu \mathrm{g}$ of the exCD90 in each injection. Freund's complete adjuvant (Sigma, Germany) in the first injection and incomplete adjuvant in the other injections were used in the immunization process. Blood samples were collected from marginal vein of the ear and allowed to clot for 1 hour at room temperature before isolation of sera. Titration of the specific polyclonal antibody against the exCD90 was then performed by ELISA with 1:1000 dilutions of rabbit normal serum and $5 \mu \mathrm{g} / \mathrm{mL}$ of 5E10 anti-CD90 monoclonal antibody as negative and positive controls respectively. Anti-mouse HRP conjugate (1:4000) and anti-rabbit HRP conjugate (1:3000) (Sigma, Germany) were used as secondary antibodies for positive control and negative control or test (immunized rabbit serum) respectively.

\section{2-5- In vivo binding study:}

Peripheral human blood was collected $(2 \mathrm{~mL})$ and diluted by adding $2 \mathrm{~mL}$ of PBS. Peripheral blood mononuclear cells (PBMCs) were isolated by density gradient separation method using $3 \mathrm{~mL}$ of Lympholyte ${ }^{\circledR}$-Mammal (Cedarlane, Canada) and centrifugation at $800 \mathrm{~g}$ for 20 minute at $25^{\circ} \mathrm{C}$ in a swinging-bucket rotor without brake. The harvested PBMCs were washed with PBS twice. The cells were suspended in ice cold PBS containing 4\% FBS $\left(2.5 \times 10^{5}\right.$ cells in $\left.100 \mu \mathrm{l}\right)$. The 5E10 anti-CD90 monoclonal 
antibody $(2 \mu \mathrm{g})$, diluted immunized rabbit serum (1/50) and diluted normal rabbit serum $(1 / 50)$ transferred to assay tubes containing $2.5 \times 10^{5}$ cells. The tubes were incubated for 1

$\mathrm{h}$ at $4^{\circ} \mathrm{C}$. The cells were washed 2 times by PBS containing $4 \%$ FBS and centrifuged at $400 \mathrm{~g}$ for $5 \mathrm{~min}$. The cell pellets were resuspended in PBS, 4\% FBS containing goat antimouse IgG FITC conjugate (1:1000) (Sigma, Germany) and goat anti-rabbit IgG FITC conjugate (1:1000) (Sigma, Germany) as secondary antibodies for positive control and negative control or test respectively. The tubes were incubated at $4^{\circ} \mathrm{C}$ for $1 \mathrm{~h}$ in the dark. The staining was analyzed by flow cytometer (Partec, Germany).

\section{3- Results:}

\section{3-1- Cloning and expression of CD90 gene:}

According to the size of exCD90 gene, $348 \mathrm{bp}$, and designed primers and their binding sites, a band in size of 378 bp was expected in colony PCR of recombinant pET15bexCD90 vector which was observed on the agarose gel (data not shown). The desired bands of enzymatic digestion with EcoRI restriction enzyme, $486 \mathrm{bp}$ and $5422 \mathrm{bp}$, have been observed too (data not shown). A protein band in molecular size of about $14 \mathrm{kDa}$ was seen in the SDS-PAGE of purified protein (Figure 2A) which was detected by the anti-CD90 monoclonal antibody in western blotting (Figure 2B).

\section{3-2- In vitro binding study:}


Interaction of antigen-antibody has been evaluated by ELISA. A significant positive signal $\left(\mathrm{OD}_{450} 1.5\right)$ was obtained for sample of exCD90-anti CD90 monoclonal antibody (Figure 3A). In the second ELISA, a strong immune response to the exCD90 was detected in sample of immunized rabbit serum $\left(\mathrm{OD}_{450} 1.3\right)$ in comparison with normal serum $\left(\mathrm{OD}_{450} 0.2\right)$ (Figure 3B).

\section{3-3- In vivo binding study:}

The ability of generated rabbit polyclonal antibodies by exCD90 recombinant protein in recognition and binding to native human CD90 antigen on the surface of PBMCs was assessed by flow cytometry. About 55\% of PBMCs were stained by immunized serum sample in comparison with $5 \%$ of staining by normal serum sample and $58 \%$ by positive control (5E10 mAb) (Figure 4).

\section{4- Discussion:}

The CD90 (Thy-1) biomarker is a heavily N-glycosylated protein expressing on the surface of normal and cancer stem cells. This protein participates in T-cell activation [26], inhibition of neurite outgrowth [27], apoptotic signaling [28], tumor suppression $[29,30]$ and fibroblast proliferation and migration [31-33]. Glycosylation is an important and in some cases crucial parameter for activity of recombinant proteins; however, it is depended on the biologic structural function of the protein. For instance, the E. coli- 
derived unglycosylated form of the therapeutic interferon gamma (IFN- $\gamma$ ), Actimmune ${ }^{\circledR}$, displays a biological activity similar to the native glycosylated human IFN- $\gamma$ [34]. Therefore, if glycosylation not be considered as a limitation, using non-expensive, fast and high yield prokaryotic expression system instead of expensive and complicated eukaryotic system is preferred.

In this study, the extra-membrane domain of human CD90 (exCD90, $\mathrm{Gln}_{15}$ to $\mathrm{Cys}_{130}$ ) was expressed in E.coli prokaryotic expression system. A 14 kDa-recombinant polypeptide was successfully expressed. By binding of the 5E10 anti-CD90 monoclonal antibody [25] to the exCD90 in western blotting and ELISA, the integrity of antigenic epitope in this E.coli-derived recombinant protein was initially confirmed.

Rabbit humoral immunity was stimulated by exCD90 to raise antibody. The produced polyclonal antibodies (pAb) in the ELISA based binding study had an appropriate interaction with coated exCD90 in the ELISA plate. Therefore, exCD90 protein elicited specific antibodies in rabbit serum which was comparable to the 5E10 anti-CD90 monoclonal antibody $\left(\mathrm{OD}_{450 \mathrm{~nm}} 1.3\right.$ for $\mathrm{pAb}$ in comparison with 1.5 for $\left.5 \mathrm{E} 10 \mathrm{mAb}\right)$. Final confirmation of exCD90 antigenic integrity was achieved in the flow cytometric analysis of $\mathrm{CD} 90^{+}$cells florescent staining in the sample PBMC cells. The produced rabbit antiexCD90 pAb stained the $\mathrm{CD}^{+} 0^{+}$cell population as well as $5 \mathrm{E} 10 \mathrm{mAb}(54.5 \%$ for rabbit anti-exCD90 pAb in comparison with $57.7 \%$ for 5E10 anti-CD90 mAb). 


\section{5- Conclusions:}

As a conclusion, the expressed exCD90 in E.coli prokaryotic host cell had a correct conformation and appropriate antigenic integrity to produce antibodies with affinity to the native $\mathrm{CD} 90$ marker on the $\mathrm{CD} 90^{+}$cells. Therefore, this recombinant antigen can be used in production of anti-CD90 polyclonal and monoclonal antibodies as well as CD90 affinity columns or beads.

\section{6- Acknowledgements:}

This work was funded by Iran National Science Foundation (INSF) for project No. INSF91004810.

\section{7- References:}

[1] M. Al-Hajj, M.S. Wicha, A. Benito-Hernandez, S.J. Morrison, M.F. Clarke, Prospective identification of tumorigenic breast cancer cells. Proceedings of the National Academy of Sciences of the United States of America 100 (2003) 3983-3988.

[2] S.K. Singh, C. Hawkins, I.D. Clarke, J.A. Squire, J. Bayani, T. Hide, R.M. Henkelman, M.D. Cusimano, P.B. Dirks, Identification of human brain tumour initiating cells. Nature 432 (2004) 396-401.

[3] C.A. O'Brien, A. Pollett, S. Gallinger, J.E. Dick, A human colon cancer cell capable of initiating tumour growth in immunodeficient mice. Nature 445 (2007) 106-110.

[4] A. Eramo, F. Lotti, G. Sette, E. Pilozzi, M. Biffoni, A. Di Virgilio, C. Conticello, L. Ruco, C. Peschle, R. De Maria, Identification and expansion of the tumorigenic lung cancer stem cell population. Cell death and differentiation 15 (2008) 504-514.

[5] M.S. Wicha, Targeting self-renewal, an Achilles' heel of cancer stem cells. Nature medicine 20 (2014) 14-15. 
[6] J. He, Y. Liu, T. Zhu, J. Zhu, F. Dimeco, A.L. Vescovi, J.A. Heth, K.M. Muraszko, X. Fan, D.M. Lubman, CD90 is identified as a candidate marker for cancer stem cells in primary high-grade gliomas using tissue microarrays. Molecular \& cellular proteomics : MCP 11 (2012) M111 010744.

[7] E.W. Ades, R.K. Zwerner, R.T. Acton, C.M. Balch, Isolation and partial characterization of the human homologue of Thy-1. The Journal of experimental medicine 151 (1980) 400-406.

[8] S.M. Haeryfar, D.W. Hoskin, Thy-1: more than a mouse pan-T cell marker. Journal of immunology 173 (2004) 3581-3588.

[9] T. Seki, N. Spurr, F. Obata, S. Goyert, P. Goodfellow, J. Silver, The human Thy-1 gene: structure and chromosomal location. Proceedings of the National Academy of Sciences of the United States of America 82 (1985) 6657-6661.

[10] J.M. Crawford, R.W. Barton, Thy-1 glycoprotein: structure, distribution, and ontogeny. Laboratory investigation; a journal of technical methods and pathology 54 (1986) 122-135.

[11] L. Leyton, J.S. Hagood, Thy-1 modulates neurological cell-cell and cell-matrix interactions through multiple molecular interactions. Advances in neurobiology 8 (2014) 3-20.

[12] J.E. Dennis, K. Esterly, A. Awadallah, C.R. Parrish, G.M. Poynter, K.L. Goltry, Clinical-scale expansion of a mixed population of bone-marrow-derived stem and progenitor cells for potential use in bone-tissue regeneration. Stem cells 25 (2007) 2575-2582.

[13] M.B. Herrera, S. Bruno, S. Buttiglieri, C. Tetta, S. Gatti, M.C. Deregibus, B. Bussolati, G. Camussi, Isolation and characterization of a stem cell population from adult human liver. Stem cells 24 (2006) 2840-2850.

[14] Y.Y. Dan, K.J. Riehle, C. Lazaro, N. Teoh, J. Haque, J.S. Campbell, N. Fausto, Isolation of multipotent progenitor cells from human fetal liver capable of differentiating into liver and mesenchymal lineages. Proceedings of the National Academy of Sciences of the United States of America 103 (2006) 9912-9917.

[15] C.A. Lazaro, E.J. Croager, C. Mitchell, J.S. Campbell, C. Yu, J. Foraker, J.A. Rhim, G.C. Yeoh, N. Fausto, Establishment, characterization, and long-term maintenance of cultures of human fetal hepatocytes. Hepatology 38 (2003) 1095-1106.

[16] N. Khan, H. Mukhtar, Dietary agents for prevention and treatment of lung cancer. Cancer letters 359 (2015) 155-164.

[17] C.H. Sukowati, B. Anfuso, G. Torre, P. Francalanci, L.S. Croce, C. Tiribelli, The expression of CD90/Thy-1 in hepatocellular carcinoma: an in vivo and in vitro study. PloS one 8 (2013) e76830.

[18] R. Grisshammer, C.G. Tate, Overexpression of integral membrane proteins for structural studies. Quarterly reviews of biophysics 28 (1995) 315-422.

[19] C.G. Tate, R. Grisshammer, Heterologous expression of G-protein-coupled receptors. Trends in biotechnology 14 (1996) 426-430.

[20] S.C. Makrides, Strategies for achieving high-level expression of genes in Escherichia coli. Microbiological reviews 60 (1996) 512-538.

[21] M. Uhlen, T. Moks, Gene fusions for purpose of expression: an introduction. Methods in enzymology 185 (1990) 129-143.

[22] M. Murby, M. Uhlen, S. Stahl, Upstream strategies to minimize proteolytic degradation upon recombinant production in Escherichia coli. Protein expression and purification 7 (1996) 129-136.

[23] N. Sheibani, Prokaryotic gene fusion expression systems and their use in structural and functional studies of proteins. Preparative biochemistry \& biotechnology 29 (1999) 77-90.

[24] Alphalyse.com, Protocol for Silver Staining of Gels; Optimized for Mass Spectrometry and Protein Identification, http://www.alphalyse.com/silver-stain-protocols.html, 2015.

[25] W. Craig, R. Kay, R.L. Cutler, P.M. Lansdorp, Expression of Thy-1 on human hematopoietic progenitor cells. The Journal of experimental medicine 177 (1993) 1331-1342. 
[26] E. Barboni, A.M. Gormley, F.B. Pliego Rivero, M. Vidal, R.J. Morris, Activation of T lymphocytes by cross-linking of glycophospholipid-anchored Thy-1 mobilizes separate pools of intracellular second messengers to those induced by the antigen-receptor/CD3 complex. Immunology 72 (1991) 457-463.

[27] M.C. Tiveron, E. Barboni, F.B. Pliego Rivero, A.M. Gormley, P.J. Seeley, F. Grosveld, R. Morris, Selective inhibition of neurite outgrowth on mature astrocytes by Thy-1 glycoprotein. Nature 355 (1992) 745-748.

[28] N. Fujita, Y. Kato, M. Naito, T. Tsuruo, A novel anti-Thy-1 (CD90) monoclonal antibody induces apoptosis in mouse malignant T-lymphoma cells in spite of inducing bcl-2 expression. International journal of cancer Journal international du cancer 66 (1996) 544-550.

[29] H.L. Lung, D.K. Bangarusamy, D. Xie, A.K. Cheung, Y. Cheng, M.K. Kumaran, L. Miller, E.T. Liu, X.Y. Guan, J.S. Sham, Y. Fang, L. Li, N. Wang, A.I. Protopopov, E.R. Zabarovsky, S.W. Tsao, E.J. Stanbridge, M.L. Lung, THY1 is a candidate tumour suppressor gene with decreased expression in metastatic nasopharyngeal carcinoma. Oncogene 24 (2005) 6525-6532.

[30] H.R. Abeysinghe, S.J. Pollock, N.L. Guckert, Y. Veyberman, P. Keng, M. Halterman, H.J. Federoff, J.P. Rosenblatt, N. Wang, The role of the THY1 gene in human ovarian cancer suppression based on transfection studies. Cancer genetics and cytogenetics 149 (2004) 1-10.

[31] K.M. Fries, T. Blieden, R.J. Looney, G.D. Sempowski, M.R. Silvera, R.A. Willis, R.P. Phipps, Evidence of fibroblast heterogeneity and the role of fibroblast subpopulations in fibrosis. Clinical immunology and immunopathology 72 (1994) 283-292.

[32] J.S. Hagood, A. Mangalwadi, B. Guo, M.W. MacEwen, L. Salazar, G.M. Fuller, Concordant and discordant interleukin-1-mediated signaling in lung fibroblast thy-1 subpopulations. American journal of respiratory cell and molecular biology 26 (2002) 702-708.

[33] T.H. Barker, H.E. Grenett, M.W. MacEwen, S.G. Tilden, G.M. Fuller, J. Settleman, A. Woods, J. Murphy-Ullrich, J.S. Hagood, Thy-1 regulates fibroblast focal adhesions, cytoskeletal organization and migration through modulation of p190 RhoGAP and Rho GTPase activity. Experimental cell research 295 (2004) 488-496.

[34] G. Walsh, The cytokines: the interferon family, in: G. Walsh (Ed.) Pharmaceutical biotechnology: concepts and applications, John Wiley \& Sons, Ltd, 2007, pp. 225-232.

\section{Figure legends:}

Figure 1. The amino acid and nucleotide sequences of exCD90. The amino acid sequence of extra-membrane domain of human CD90 gene (A) was codon optimized for E.coli. NcoI and Bam $\mathrm{HI}$ restriction sites and a $6 \times$ His tag were included in the sequence $(B)$. 
Figure 2. A) SDS-PAGE analysis of expressed exCD90. Left to right: $2 \mu \mathrm{l}$ of transformed E.coli cell lysate, $2 \mu \mathrm{l}$ of flow-through of Ni-NTA purification, $2 \mu \mathrm{l}$ of final wash sample, $5 \mu \mathrm{g}$ of purified exCD90 and pre-stained protein marker (SinaClon, Iran). B) Western blot analysis of purified exCD90. The exCD90 protein band was detected by the anti-CD90 monoclonal antibody.

Figure 3. The ELISA results of exCD90 using $5 E 10$ anti-CD90 monoclonal antibody (the positive control). A) The anti-CD90 $\mathrm{mAb}$ detected the coated exCD90 recombinant protein $(0.2$ $\mu g$ per well) with a strong positive signal. B) Evaluation of immunologic response from exCD90 antigenicity in rabbit serum. The OD value of 1.3 was obtained for the tested sample.

Figure 4: Flow cytometric analysis of antibody-antigen binding. Human PBMC was treated by A) 1/50 dilution of immunized rabbit serum containing anti-exCD90 polyclonal antibody, B) Two $\mu \mathrm{g}$ of commercial anti-CD90 monoclonal antibody, C) 1/50 dilution of normal rabbit serum, and D) $P B S$. 
Ncol

CCATGGCGCAGGTTTCTCGTGGTCAGAAAGTTACCTCTCTGACCGCTTGCCTGGTTGACCAGTCTCTGCGTCTGGA CTGCCGTCACGAAAACACCTCTTCTTCTCCGATCCAGTACGAATTCTCTCTGACCCGTGAAACCAAAAAACACGTTC TGTTCGGTACCGTTGGTGTTCCGGAACACACCTACCGTTCTCGTACCAACTTCACCTCTAAATACAACATGAAAGTT CTGTACCTGTCTGCTITCACCTCTAAAGACGAAGGTACCTACACCTGCGCTCTGCACCACTCTGGTCACTCTCCGCC GATCTCTTCTCAGAACGTTACCGTTCTGCGTGACAAACTGGTTAAATGCCATCATCATCATCATCACTAAGGATCC

(A)

$6 \times$ His tag

$\mathrm{BamHI}$

MAQVSRGQKVTSLTACLVDQSLRLDCRHENTSSSPIQYEFSLTRETKKHVLFGTVGVPEHTYRSRTNFTSKYNMKVLYLS AFTSKDEGTYTCALHHSGHSPPISSQNVTVLRDKLVKCHHHHHH

(B) 


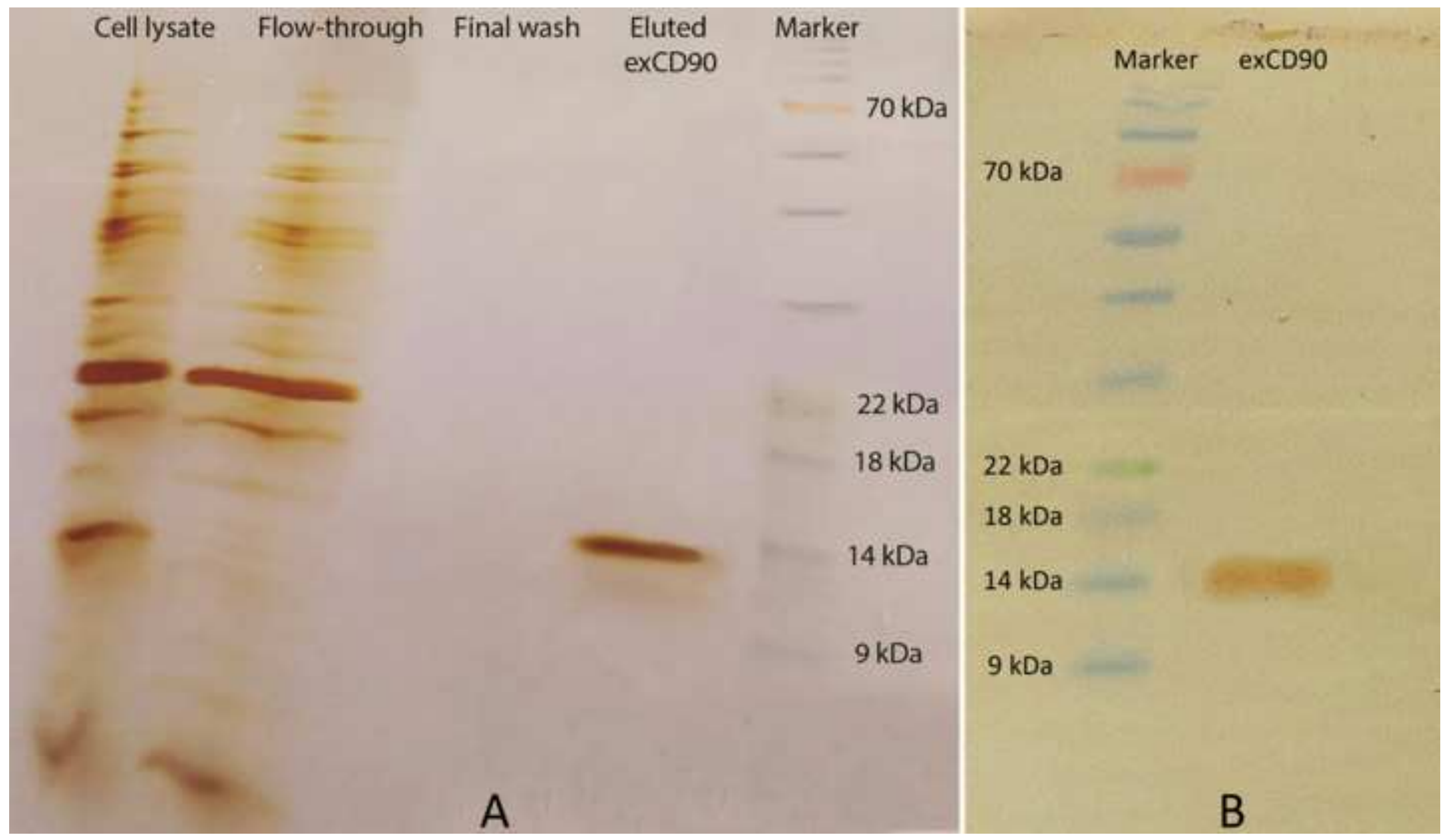

$\begin{array}{lll}\text { Cell lysate Flow-through Final wash } & \begin{array}{c}\text { Eluted } \\ \text { exCD90 }\end{array} & \text { Marker }\end{array}$

$18 \mathrm{kDa}$

$14 \mathrm{kDa}$

$9 \mathrm{kDa}$
$14 \mathrm{kDa}$

9 kDa
Marker exCD90

B



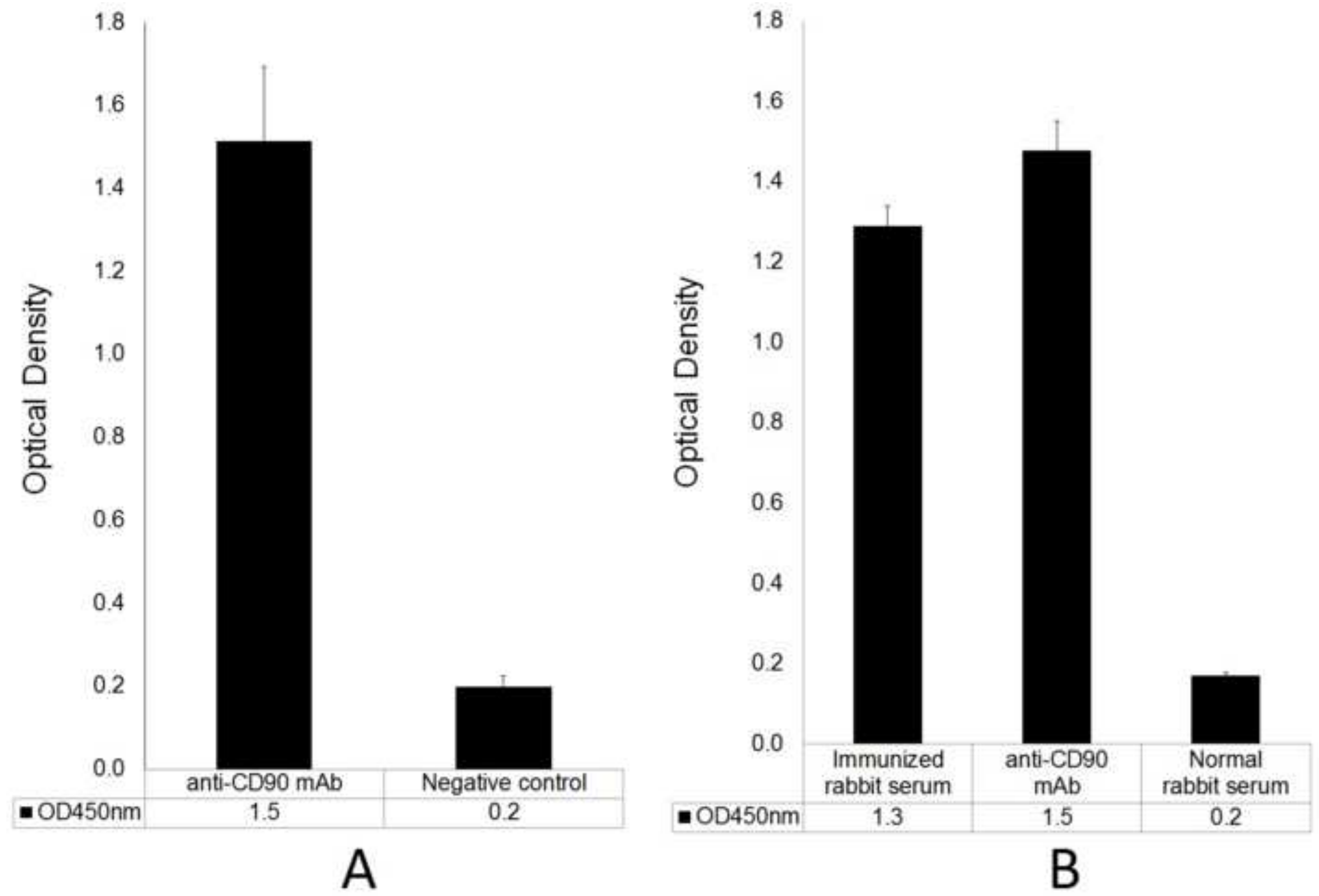

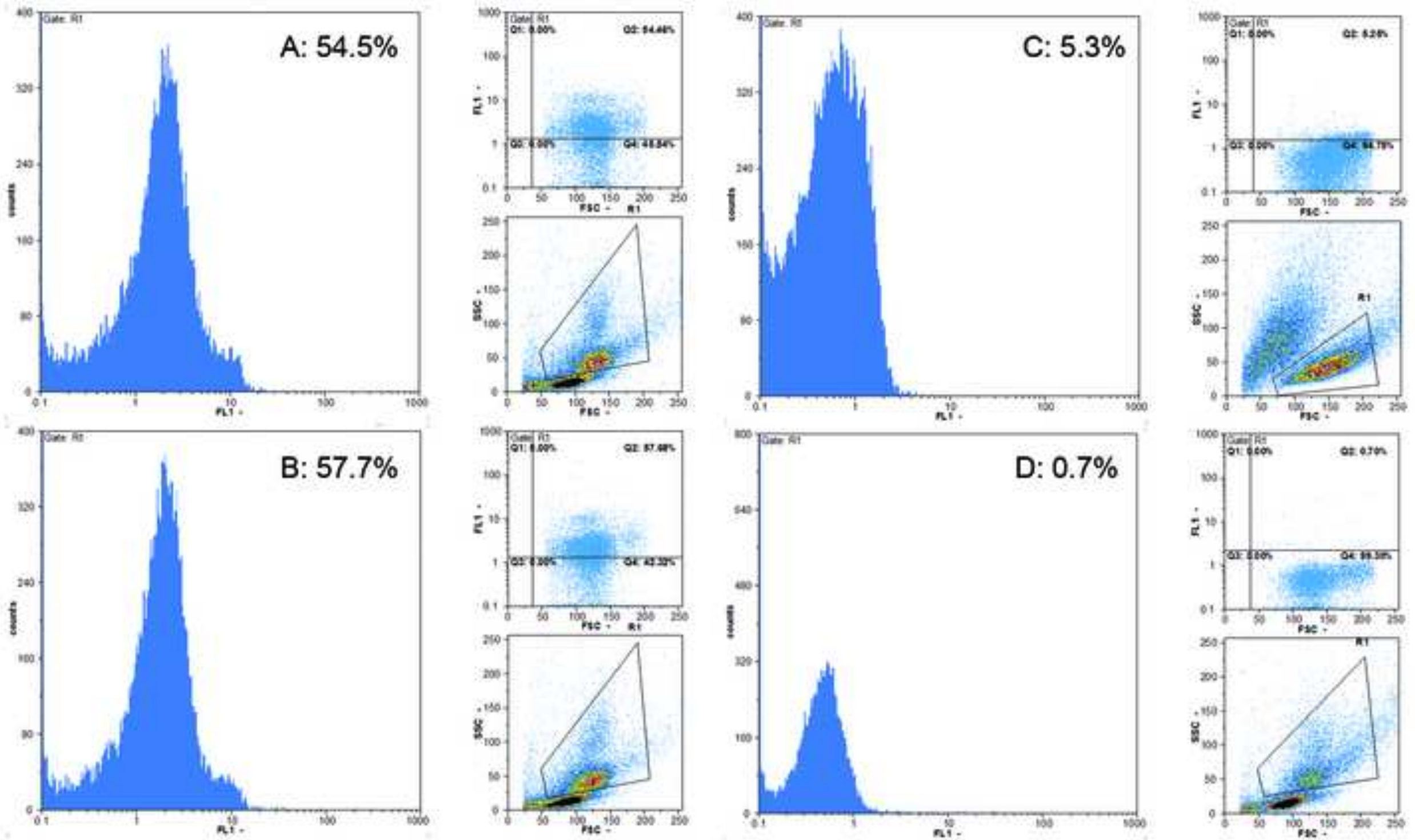